\title{
TINGKAT EFISIENSI TEKNIS USAHATANI PADI SAWAH DI DESA TAMBAKJATI, KECAMATAN PATOKBEUSI, KABUPATEN SUBANG, PROVINSI JAWA BARAT
}

\author{
LEVEL OF TECHNICAL EFFICIENCY RICE FARMING IN TAMBAKJATI \\ VILLAGE, PATOKBEUSI SUBDISTRICT, SUBANG REGENCY, WEST JAVA
}

\author{
Gina Rahnanita*, Nur Syamsiyah \\ Program Studi Agribisnis, Departemen Sosial Ekonomi, Fakultas Pertanian, \\ Universitas Padjadjaran, Sumedang, Jawa Barat \\ *Email: ginarahnanita@gmail.com \\ (Diterima 27-03-2018; Disetujui 11-05-2018)
}

\begin{abstract}
ABSTRAK
Kabupaten Subang merupakan sentra produksi padi ketiga di Jawa Barat. Usahatani padi sudah menjadi kegiatan utama dan turun temurun di Kecamatan Patokbeusi. Namun pada tahun 2016, Kecamatan Patokbeusi mengalami penurunan produktivitas padi sebanyak 1,4 ton/Ha. Penelitian ini bertujuan untuk menganalisis tingkat efisiensi teknis usahatani padi sawah, serta mengetahui faktor-faktor yang mempengaruhi produktivitas usahatani. Penelitian ini dilakukan di Desa Tambakjati, Kecamatan Patokbeusi, Kabupaten Subang, Jawa Barat. Teknik pengambilan data dilakukan secara cluster random sampling dengan metode survei terhadap petani padi sawah, dengan responden berjumlah 55 orang. Desain penelitian ini adalah kuantitatif untuk menyatakan pengaruh faktor-faktor produksi terhadap produktivitas usahatani dan tingkat efisiensi teknis. Metode penelitian ini menggunakan analisis fungsi produksi CobbDouglas dengan pendekatan frontier stokastic. Hasil penelitian menunjukkan bahwa rata-rata tingkat efisiensi teknis usahatani padi adalah 0,037. Artinya usahatani padi di Desa Tambakjati tidak efisien dalam menggunakan input produksi, maka penggunaannya harus dikurangi. Faktor-faktor poduksi yang berpengaruh nyata $(\alpha=5 \%)$ terhadap produktivitas usahatani adalah lahan, tenaga kerja, bibit, urea, dan SP-36.
\end{abstract}

Kata kunci: Padi sawah, efisiensi teknis, frontier stokastik

\begin{abstract}
Subang Regency is the third rice production center in West Java. Rice farming has become the main activity and hereditary in the District Patokbeusi. However, in 2016, Patokbeusi subdistrict decreased rice productivity by 1.4 tons/ha. In this study aims to analyze the technical efficiency level of rice farming, and to knew the factors that affect farm productivity. This research was conducted in Tambakjati Village, Patokbeusi Subdistrict, Subang Regency, West Java. Data collection technique was conducted by survey with sampling method to rice farmer, which amounted to 55 people. The design of this studied is quantitative to express the effect of production factors on farming productivity. This research method used analysis of Cobbdouglas production function with stockastic frontier approach to knew the level of technical efficiency. The results showed that the average technical efficiency level of rice farming is 0,037. It means that rice farming in Tambakjati Village has not been efficient in using input production yet, so its use should be added. Production factors that have significant effect ( $\alpha=$ $5 \%$ ) on farming productivity are land, labour, seed, urea, and SP-36.
\end{abstract}

Keywords: Rice farming, technical efficiency, stockastic frontier 
Tingkat Efisiensi Teknis Usahatani Padi Sawah Di Desa Tambakjati, Kecamatan Patokbeusi, Kabupaten Subang, Provinsi Jawa Barat

Gina Rahnanita, Nur Syamsiyah

\section{PENDAHULUAN}

Padi menjadi salah satu komoditas yang strategis untuk dikembangkan di Indonesia. Menurut Budi Yoko et.al (2014) padi merupakan bahan pangan utama bagi sebagian besar masyarakat Indonesia. Dengan semakin bertambahnya jumlah penduduk di Indonesia, maka permintaan beras akan semakin meningkat. Pada tahun 2016, konsumsi beras di Indonesia mencapai $86,82 \mathrm{~kg} / \mathrm{kapita} / \mathrm{tahun}$ (BPS, 2017). Oleh karena itu, program peningkatan produksi padi selalu mendapatkan prioritas tinggi dari pemerintah untuk mewujudkan ketahanan pangan dan kesejahteraan petani.

Jawa Barat merupakan salah satu sentra produksi padi yang menyandang kebutuhan pangan nasional. Produktivitas padi Jawa Barat sebesar 5,97 ton/Ha dan jumlah rumah tangga pertanian tanaman pangan adalah sebanyak 2.492.459 rumah tangga. Menurut laporan hasil Sensus Pertanian 2013, struktur penguasaan lahan di Jawa Barat masih didominasi oleh petani yang memiliki luas lahan 5.000-9.999 $\mathrm{m}^{2}$ yaitu sebesar $15,2 \%$, sedangkan untuk golongan luas lebih dari
$10.000 \mathrm{~m}^{2}$ yaitu sebesar $9,34 \%$. Namun, masih terdapat rumah tangga usaha pertanian yang menguasai lahan $<5.000$ $\mathrm{m}^{2}$ yaitu sebesar $75,46 \%$. Dari hasil penggolongan penguasaan lahan rumah tangga usaha pertanian di Jawa Barat masih didominasi oleh petani gurem yang mempunyai luas lahan kurang dari 0,5 Ha. Menurut Saptana (2012) kapasitas pangan Jawa Barat terkendala oleh kompetisi penggunaan lahan, perubahan iklim yang ekstrim, kurangnya infrastruktur pertanian, dan degradasi sumberdaya pertanian. Keadaan tersebut sangat mempengaruhi tingkat efisiensi usahatani.

Kecamatan Patokbeusi merupakan penghasil padi terbesar kedua di Kabupaten Subang. Produktivitas padi di Kecamatan Patokbeusi tahun 2015 mencapai 7,6 ton/Ha lebih tinggi dari Ciasem 0,11 ton/Ha. Namun pada Tahun 2016 akibat serangan hama dan penyakit yang menyerag seluaruh areal persawahan di Kabupaten Subang, Kecamatan Patokbeusi mengalami penurunan produktivitas padi sebanyak 1,4 ton/Ha (Gambar 1). 


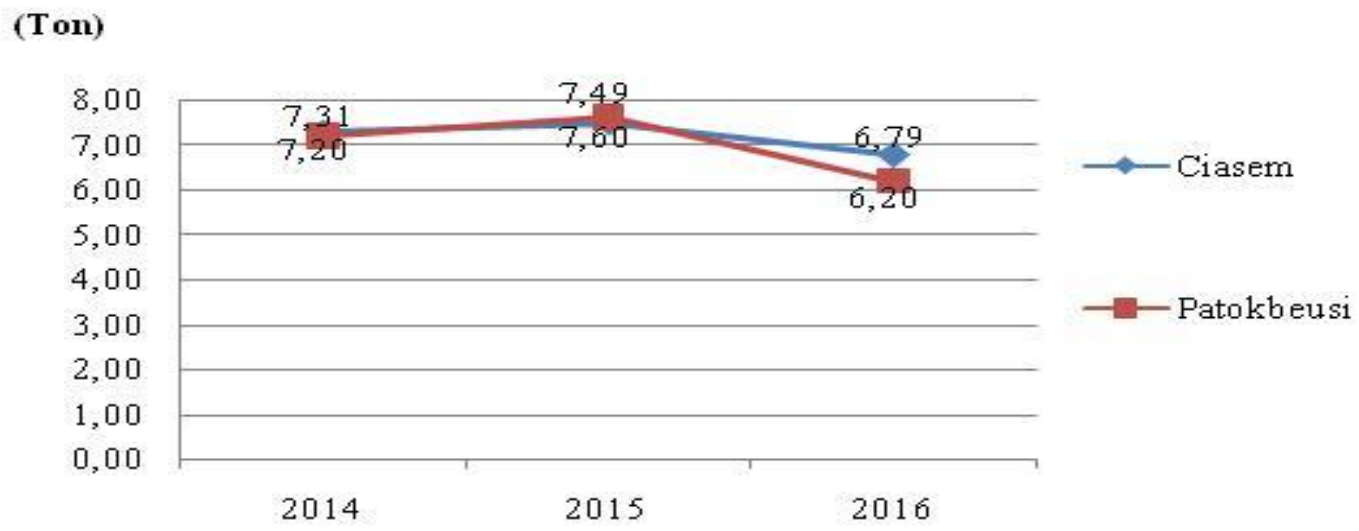

\section{Gambar 1. Produktivitas Padi di Kabupaten Subang}

Desa Tambakjati adalah desa yang memiliki hasil produksi terbesar di Kecamatan Patokbeusi yaitu 11.020 ton dengan produktivitas sebesar 7,6 ton/Ha pada tahun 2015. Luas panen di Desa Tambakjati dari 4 tahun terakhir cenderung tetap, namun produksi dan produktivitasnya dari 4 tahun terakhir berfluktuatif. Pada tahun 2014 rata-rata produktivitas padi di Desa Tambakjati sebesar 7,1 ton/Ha dan mengalami kenaikan sebesar 0,5 ton/Ha di tahun 2015 (Tabel 1).

Tabel 1. Luas Panen dan Produksi Padi di Kecamatan Patokbeusi

\begin{tabular}{clcccc}
\hline \multirow{2}{*}{ No } & \multirow{2}{*}{ Desa } & \multicolumn{2}{c}{ Luas Panen (Ha) } & \multicolumn{2}{c}{ Produksi (Ton) } \\
\cline { 3 - 6 } & & $\mathbf{2 0 1 4}$ & $\mathbf{2 0 1 5}$ & $\mathbf{2 0 1 4}$ & $\mathbf{2 0 1 5}$ \\
\hline 1 & Tanjungrasa Kidul & 852 & 852 & $6.049,2$ & 6.475 \\
2 & Tanjungrasa & 823 & 823 & $6.007,9$ & 6.255 \\
3 & Jatiragas Hilir & 1.420 & 1.420 & 10.082 & 10.792 \\
4 & Tambakjati & $\mathbf{1 . 4 5 0}$ & $\mathbf{1 . 4 5 0}$ & $\mathbf{1 0 . 2 9 5}$ & $\mathbf{1 1 . 0 2 0}$ \\
5 & Ciberes & 1.140 & 1.140 & 8.094 & 8.664 \\
6 & Gempolsari & 1.012 & 1.012 & 7.084 & 7.691 \\
7 & Rancamulya & 902 & 902 & 6.314 & 6.855 \\
8 & Rancajaya & 926 & 926 & 6.482 & 7.038 \\
9 & Rancabango & 1.020 & 1.020 & 6.834 & 7.752 \\
10 & Rancaasih & 805 & 805 & 5.474 & 6.118 \\
\hline Kecamatan & $\mathbf{1 0 . 3 5 0}$ & $\mathbf{1 0 . 3 5 0}$ & $\mathbf{7 2 . 7 1 6}$ & $\mathbf{7 8 . 6 6 0}$ \\
\hline Rata-rata & $\mathbf{1 . 0 3 5}$ & $\mathbf{1 . 0 3 5}$ & $\mathbf{7 . 2 7 1 , 6}$ & $\mathbf{7 . 8 6 6}$ \\
\hline
\end{tabular}

Sumber: BP4KP, 2017

Selain itu, sulitnya tenaga kerja dan harga pestisida yang mahal, mengakibatkan modal yang dikeluarkan petani lebih besar dibandingkan dengan pendapatannya. Dosis penggunaan pupuk dan pestisida di petani tidak sesuai dengan anjuran pemerintah sehingga kebutuhan input produksi di kalangan petani lebih banyak dibutuhkan. Maka dari itu, perlu adanya analisis efisiensi dalam usahatani padi sawah di Desa Tambakjati, Kecamatan Patokbeusi 
Tingkat Efisiensi Teknis Usahatani Padi Sawah Di Desa Tambakjati, Kecamatan Patokbeusi, Kabupaten Subang, Provinsi Jawa Barat

Gina Rahnanita, Nur Syamsiyah

sebagai salah satu upaya dalam untuk meningkatkan produktivitas padi dan pendapatan petani.

\section{METODE PENELITIAN}

Penelitian ini dilakukan di Desa Tambakjati, Kecamatan Patokbeusi, Kabupaten Subang. Pemilihian lokasi dilakukan secara purposive dengan pertimbangan bahwa Desa Tambakjati merupakan sentra produksi padi dan memiliki luas areal persawahan terluas di Kecamatan Patokbeusi. Desa Tambakjati terbagi ke dalam 11 kelompok tani padi. Dari 11 kelompok tani, diambil dua kelompok tani dengan teknik cluster random sampling yang dianggap dapat mewakili wilayah bagian utara yaitu kelompok tani Sengon 1 dan wilayah bagian selatan kelompok tani Sejahtera. Dari kedua kelompok tani tersebut, masing-masing diambil beberapa petani secara acak yang dianggap dapat mewakili seluruh petani yang ada di Desa Tambakjati. Jumlah sampel dalam penelitian ini adalah 55 orang. Penelitian ini dilaksanakan pada bulan November 2017 - Februari 2018.

Metode yang digunakan dalam penelitian ini adalah kuantitatif dengan jenis metode survei. Menurut Sugiyono (2012), penelitian kuantitatif adalah penelitian yang memperoleh data yang berbentuk angka atau data kualitatif yang diangkakan. Menurut Sarwono (2006), survei merupakan studi yang bersifat kuantitatif yang digunakan untuk meneliti suatu gejala kelompok atau perilaku indvidu. Semakin besar sampel yang diambil, survei semakin memberikan hasil yang akurat. Data yang dikumpulkan dalam penelitian ini terdiri dari data primer dan data sekunder. Data primer diperoleh dengan cara mewawancarai petani padi secara langsung dengan alat bantu kuesioner yang meliputi data usahatani padi (luas lahan, input produksi, biaya produksi, dan hasil produksi). Data sekunder diperoleh dari hasil wawancara terhadap berbagai pihak yang terkait dan sumber pustaka, seperti buku, internet, dan jurnal.

Alat analisis yang digunakan dalam penelitian ini adalah fungsi produksi Cobb-douglas dengan pendekatan produksi stokastik frontier untuk mengestimasi efisiensi teknis, serta mengetahui faktor-faktor yang mempengaruhi produktivitas usahatani padi. Menurut Sutanto, H. A., \& Imaningati, S. (2014), fungsi produksi frontier stokastic menggambarkan produksi maksimum yang berpotensi dihasilkan untuk sejumlah input produksi 
yang dikorbankan. Model ini dipilih berdasarkan beberapa pertimbangan, yaitu: (1) Penyelesaian fungsi produksi Cobb-Douglas relatif lebih mudah dibandingkan dengan fungsi yang lain, seperti fungsi kuadratik. Karena fungsi Cobb-Douglas dapat dengan mudah ditransfer ke dalam bentuk linear. (2) Hasil pendugaan garis melalui fungsi Cobb-Douglas akan menghasilkan koefisien regresi yang sekaligus juga menunjukkan besaran elastitas. Jadi besaran $b$ pada persamaan adalah angka elastisitas. Besaran elastisitas tersebut sekaligus menunjukkan tingkat besaran return to scale. Keunggulan dari pendekatan model frontier stokastic adalah adanya pelibatan disturbance term yang mewakili gangguan, kesalahan pengukuran, dan kejutan eksogen yang berada di luar kontrol unit produksi.

Fungsi Cobb-Douglas dapat dituliskan sebagai berikut:

$$
\begin{aligned}
Y= & a X_{1}^{b 1} X_{2}^{b 2} \ldots \ldots . . . X_{i}^{b i} \ldots \ldots . . . X_{n}^{b n} e^{u} \\
\operatorname{Ln} Y= & \operatorname{Ln~} a+b_{1} \ln X_{1}+b_{2} \ln X_{2}+\ldots \\
& +b_{n} \ln X_{n}+(V i-U i)
\end{aligned}
$$

Keterangan:

$\mathrm{Y}=$ Variabel terikat

$\mathrm{X} \quad=$ Variabel bebas

a $\quad=$ Konstanta

$\mathrm{b} \quad=$ Koefisien regresi

Ln = Logaritma natural

$(\mathrm{Vi}-\mathrm{Ui})=$ Error term

Dalam penelitian ini, nilai efisiensi teknisnya secara otomatis terlihat dari hasil output software STATA (Version.12). Nilai elastisitas sekaligus menunjukkan koefisien regresi masingmasing variabel independen, nilai tersebut menunjukkan besarnya persentase perubahan tingkat output yang diakibatkan oleh perubahan satu unit faktor produksi X. Alat analisis yang digunakan untuk mengukur efisiensi teknis yaitu konsep elastisitas produksi, persamaannya yaitu:

$$
\mathbf{E p}=\boldsymbol{\beta}=\mathbf{e}
$$

Keterangan:

$\beta=$ Koefisien regresi

$\mathrm{e}=$ Elastisitas

Menurut Soekartawi (2003), terdapat tiga kemungkinan yang terjadi pada konsep ini, yaitu:

1) Nilai efisiensi $=1$. Hal ini berarti bahwa usaha yang dilakukan efisien, untuk itu penggunaan faktor produksi perlu ditambah agar tercapai kondisi efisien.

2) Nilai efisiensi > 1. Hal ini berarti bahwa usaha yang dilakukan belum mencapai efisiensi, untuk itu penggunaan faktor produksi perlu ditambah agar tercapai kondisi efisien.

3) Nilai efisiensi $<1$. Hal ini berarti bahwa usaha yang dilakukan tidak efisien, untuk itu penggunaan faktor 
Tingkat Efisiensi Teknis Usahatani Padi Sawah Di Desa Tambakjati, Kecamatan Patokbeusi, Kabupaten Subang, Provinsi Jawa Barat

Gina Rahnanita, Nur Syamsiyah

produksi perlu dikurangi agar tercapai kondisi efisien.

Faktor-faktor yang diduga mempengaruhi produktivitas usahatani padi adalah luas lahan, tenaga kerja, benih, pupuk (urea, SP-36, NPK), dan pestisida (insektisida dan herbisida).

\section{HASIL DAN PEMBAHASAN}

Desa Tambakjati merupakan hasil pemekaran dari Desa Jatiragas Hilir pada tahun 1979. Luas Wilayah Desa Tambakjati yaitu $\pm 888,98$ Ha dengan luas lahan sawah yang tersedia seluas 682 Ha. Desa Tambakjati mempunyai jumlah penduduk 10.812 jiwa yang terbagi dalam 8 Dusun, terdiri dai 27 RT dan 9 RW. Desa tersebut berada pada ketinggian 10 mdpl dengan kemiringan $\pm 0,25$ derajat, curah hujan 1857,2 mm/tahun dan suhu rata-rata harian $30^{\circ} \mathrm{C}$. Keadaan tanah $100 \%$ daratan, sehingga cocok untuk dijadikan wilayah pertanian (Profil Desa Tambakjati, 2017).

Desa Tambakjati memiliki beberapa potensi sumber daya alam yang dapat dimanfaatkan hasilnya, bahkan dapat dijadikan sumber mata pencaharian untuk masyarakat Desa Tambakjati. Total luas wilayah Desa Tambakjati adalah $847,30 \mathrm{Ha}$ yang didominasi oleh areal persawahan sekitar 80,49\%, sedangkan $19,51 \%$ dari luas wilayah Desa digunakan untuk fasilitas umum, permukiman, perkantoran, kebun, dan pekarangan. Sehingga kebanyakan penduduk Desa Tambakjati memiliki mata pencaharian sebagai petani yaitu sebanyak 2.848 orang atau sekitar $23,30 \%$.

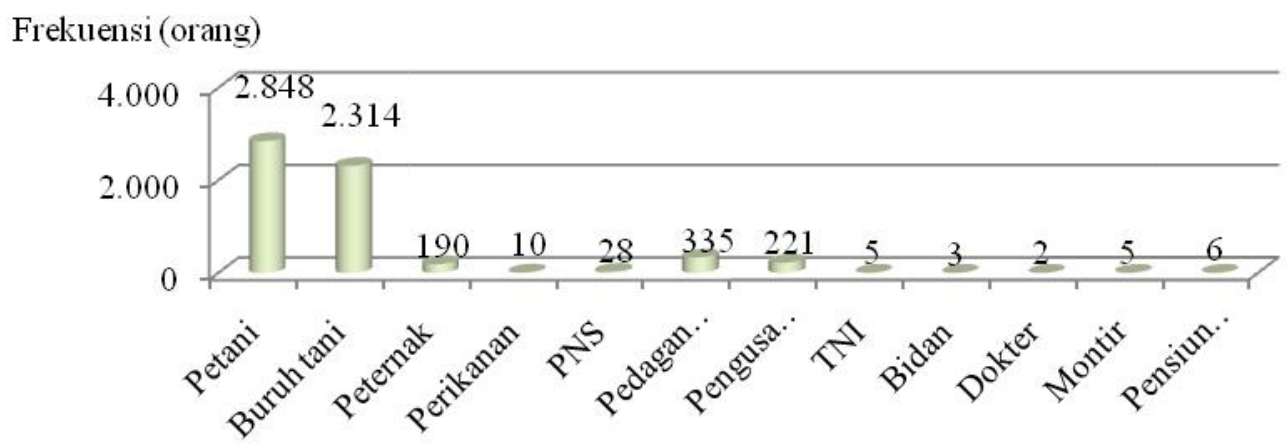

Gambar 2. Mata Pencaharian Penduduk Desa Tambakjati

Desa Tambakjati memiliki 11 kelompok tani padi sawah yang tersebar di 8 dusun. Kelompok tani di Desa Tambakjati merupakan kelompok tani hamparan, sehingga memiliki tujuan yang sama, yaitu membantu para petani dalam mencukupi segala kebutuhan input produksi untuk mencapai hasil produksi 
yang maksimal. Kegiatan kelompok tani di Desa Tambakjati diantaranya yaitu musyawarah kelompok untuk menentukan musim tanam, tanam serempak, dan mendistribusikan input produksi kepada anggota kelompok tani.

Rata-rata umur petani di Desa Tambakjati adalah 45 tahun. Hal ini menunjukkan bahwa pada umumnya petani di Desa Tambakjati tergolong ke dalam umur produktif. Dengan kondisi ini, berarti daya ingat, kondisi fisik, dan kemampuan berfikir petani masih baik. Karena faktor usia sedikit banyak akan mempengaruhi tingkat produktivitas petani dalam mengatur usahataninya.

\section{Penggunaan Faktor Produksi}

Luas lahan garapan yang diusahakan petani padi di Desa Tambakjati bervariasi. Petani yang berlahan sempit sebanyak 7,27\%, sedangkan petani padi yang berlahan sedang (0,5-1 Ha) yaitu sebanyak 60\%, dan petani yang berlahan luas sebanyak $32,73 \%$. Rata-rata luas lahan yang digarap oleh petani di Desa Tambakjati yaitu 1,62 Ha yang termasuk ke dalam kategori luas. Hal tersebut ditunjang oleh keadaan geografis dan ketersediaan lahan persawahan yang luas, sehingga penduduk Desa Tambakjati memanfaatkan keadaan tersebut untuk berusahatani padi.

Kebutuhan tenaga kerja pada usahatani padi di Desa Tambakjati cukup besar, hal tersebut dapat dilihat dari luas lahan dan jenis komoditas yang ditanam yaitu padi yang pada umumnya membutuhkan tenaga kerja yang cukup besar pada musim penanaman. Berdasarkan hasil wawancara dengan ketua GAPOKTAN, upah tenaga kerja di Desa Tambakjati dibedakan antara tenaga kerja pria dan wanita. Tenaga kerja pria diupah sebesar Rp 100.000,- /hari, sedangkan untuk tenaga kerja wanita diupah sebesar $\mathrm{Rp}$ 40.000,-/hari karena bekerja hanya 4-5 jam per hari dari jam 07.00- 12.00, biasanya dikenal dengan istilah "sabedug". Sistem pembayaran upah untuk tenaga kerja yang berasal dari luar keluarga biasanya dilakukan secara harian.

Varietas benih yang ditaman oleh para petani di Desa Tambakjati umumnya varietas Ciherang dan Inpari-64. Ratarata penggunaan benih di Desa Tambakjati untuk lahan satu hektar adalah sebanyak $18,67 \mathrm{~kg}$ dengan ratarata harga Rp 9.964/kg. Petani padi memperoleh benih dari penangkar benih yang ada di Gabungan Kelompok Tani (GAPOKTAN) Mitra Tani. Benih dari 
Tingkat Efisiensi Teknis Usahatani Padi Sawah Di Desa Tambakjati, Kecamatan Patokbeusi, Kabupaten Subang, Provinsi Jawa Barat

Gina Rahnanita, Nur Syamsiyah

gapoktan didistribusikan ke kelompok tani, kemudian petani membeli benih tersebut di kelompok tani.

Rata-rata penggunaan pupuk urea pada petani di responden adalah $233,8 \mathrm{~kg}$ per rata-rata luas lahan (1,68 Ha) per musim. Pemupukan urea dilakukan dua kali dalam 1 kali musim tanam. Pemupukan yang pertama ketika padi berumur 20 hari dengan dosis $133,8 \mathrm{~kg}$ per luas lahan rata-rata, dan pemupukan susulan dilakukan setelah padi berumur 50 hari dengan dosis $100 \mathrm{~kg}$ per rata-rata luas lahan.

Pupuk susulan lain yaitu SP-36 dan NPK diberikan ketika padi sudah berumur 40 hari. Pupuk SP-36 rata-rata digunakan dengan dosis 190,3 $\mathrm{kg}$ per rata-rata luas lahan $(1,68 \mathrm{Ha})$ per musim, sedangkan pupuk NPK yang digunakan rata-rata sebanyak $231,8 \mathrm{~kg}$ per rata-rata luas lahan per musim.

Pestisida yang digunakan oleh petani di Desa Tambakjati sudah sesuai dengan jenis penyakitnya. Pestisida tersebut terdiri dari insektisida (untuk serangga) dan herbisida (untuk gulma). Penyemprotan pestisida biasanya dilakukan satu minggu sekali atau disesuaikan dengan intensitas serangan hama dan penyakit. Umumnya hama yang menyerang tanaman padi di Desa
Tambakjati adalah wereng dan penggerek batang padi, sedangkan penyakit yang menyerang adalah klowor atau penyakit mejen pada padi. Pada tahun 2016, produktivitas padi di Desa Tambakjati menurun sebesar 0,11 ton/ha, hal tersebut dikarenakan penyakit klowor yang menyerang seluruh areal persawahan di Kabupaten Subang. Penyakit kerdil hampa dapat ditularkan oleh hama wereng cokelat, infeksi virus tersebut dapat menyebabkan hasl tanaman menurun bahkan tidak menghasilkan biji atau buah. Gejala penyakit kerdil hampa diawali dengan tanaman tidak tumbuh, daun bendera melintir, dan malai tidak keluar atau keluar sebagian tetapi hampa. Tanaman yang terinfeksi akan bertahan sampai dewasa, tetapi hanya menghasilkan sedikit malai yang kecil berwarna cokelat dan bulirnya hampa. Maka dari itu, penggunaan pupuk dan pestisida di kalangan petani cukup banyak.

\section{Analisis Data}

Dalam analisis ini data ditransformasikan ke dalam bentuk logaritma natural (Ln) agar dapat diregresi secara linear. Berdasarkan data yang telah dikumpulkan di lapangan, untuk melihat pengaruh variabel lahan 
(X1), tenaga kerja (X2), benih (X3), urea (X4), SP-36 (X5), NPK (X6), insektisida (X7), dan herbisida (X8) terhadap produktivitas (Y) dapat dianalisis dari koefisien masing-masing variabel. Dengan menggunakan model pendekatan produksi frontier sekaligus akan mengetahui nilai koefisien dari masingmasing variabel independen dapat dihitung dengan bantuan computer melalui program software STATA (Version.12) dengan hasil sebagai berikut:

Tabel 2. Hasil Estimasi Fungsi Produksi Frontier Stokastic

\begin{tabular}{|c|c|c|c|}
\hline No. & Variabel & Koefisien & t-hitung \\
\hline 1 & Lahan $(\mathrm{X} 1)$ & $-0,690$ & 0,000 \\
\hline 2 & Tenaga Kerja (X2) & 0,222 & 0,004 \\
\hline 3 & Benih (X3) & 0,404 & 0,000 \\
\hline 4 & Urea (X4) & 0,613 & 0,000 \\
\hline 5 & SP-36 (X5) & $-0,181$ & 0,035 \\
\hline 6 & NPK (X6) & $-0,065$ & 0,189 \\
\hline 7 & Insektisida (X7) & $-0,069$ & 0,292 \\
\hline 8 & Herbisida (X8) & 0,060 & 0,106 \\
\hline 9 & Konstanta & 18,080 & 0,000 \\
\hline 10 & $\mathrm{R}^{2}$ & 0,9987 & \\
\hline
\end{tabular}

\section{1) Faktor-Faktor} Mempengaruhi Usahatani Padi Sawah

Dari hasil estimasi di atas persamaan yang telah dilogaritmakan menjadi model regresi linear berganda. Adapun model fungsi produksi padi sawah diperoleh persamaan sebagai berikut:

$$
\begin{aligned}
\operatorname{LnY}= & 18,080-0,690 \mathrm{X}_{1}+0,222 \mathrm{X}_{2}+ \\
& 0,404 \mathrm{X}_{3}+0,613 \mathrm{X}_{4}-0,181 \mathrm{X}_{5}- \\
& 0,065 \mathrm{X}_{6^{-}}-0,069 \mathrm{X}_{7}+0,060 \mathrm{X}_{8}
\end{aligned}
$$

Keterangan:

$\mathrm{Y}=$ Produktivitas $(\mathrm{kg} / \mathrm{Ha})$

$\mathrm{X}_{1}=$ Lahan $(\mathrm{Ha})$

$\mathrm{X}_{2}=$ Tenaga Kerja (HOK)

$\mathrm{X}_{3}=$ Benih $(\mathrm{kg})$

$\mathrm{X}_{4}=$ Urea $(\mathrm{kg})$

$\mathrm{X}_{5}=\mathrm{SP}-36(\mathrm{~kg})$

$\mathrm{X}_{6}=\mathrm{NPK}(\mathrm{kg})$

$\mathrm{X}_{7} \quad=$ Insektisida $(\mathrm{kg})$
$\mathrm{X}_{8} \quad=$ Herbisida $(\mathrm{kg})$

Berdasarkan hasil estimasi fungsi produksi usahatani padi sawah di Desa Tambakjati dengan fungsi produksi Cobb-Douglas menggunakan software STATA, input awal yang digunakan telah ditransformasikan ke dalam bentuk logaritma natural (Ln) maka satuan yang dituliskan menjadi persen. Analisis hasil model estimasi diketahui bahwa nilai $\mathrm{R}^{2}$ sebesar 0,9987, artinya bahwa faktorfaktor produksi secara bersama-sama mempengaruhi produktivitas usahatani padi sawah di Desa Tambakjati sebesar $99,87 \%$, sedangkan sisanya dipengaruhi oleh faktor lain yansg tidak diteliti dalam 
Tingkat Efisiensi Teknis Usahatani Padi Sawah Di Desa Tambakjati, Kecamatan Patokbeusi, Kabupaten Subang, Provinsi Jawa Barat

Gina Rahnanita, Nur Syamsiyah

penelitian ini. Faktor-faktor yang mempunyai pengaruh positif tehadap produktivitas usahatani di Desa Tambakjati diantaranya yaitu tenaga kerja, benih, urea, dan herbisida. Artinya setiap kenaikan faktor produksi tersebut sebesar 1\%, maka akan menaikkan produktivitas sebesar nilai koefisien regresi faktor produksi tersebut. Namun jika diuji secara terpisah dengan cara membandingkan t-hitung dan tingkat signifikansi 5\%, maka hasil estimasi tersebut akan berbeda. Faktor-faktor produksi yang berpengaruh nyata pada tingkat signifikansi $5 \%$ yaitu lahan, tenaga kerja, benih, urea, dan SP-36.

\section{2) Return To Scale}

Return to scale (RTS) bertujuan untuk mengetahui apakah kegiatan dari usaha yang diteliti tersebut mengikuti kaidah increasing, constant, atau decreasing to scale. Keadaan skala usaha return to scale dari usaha tani yang diteliti dapat diketahui dari penjumlahan koefisien regresi semua faktor produksi. Menurut Soekartawi terdapat tiga kemungkinan dalam nilai return to scale:

a. Decreasing return to scale, bila (b1 + b2 $+\ldots .+$ bn $)<1$. Dalam keadaan demikian, dapat diartikan bahwa proporsi penambahan faktor produksi akan menghasilkan tambahan produksi yang proporsinya lebih kecil.

b. Constant return to scale, bila (b1 + b2 $+\ldots .+$ bn $)=1$. Dalam keadaan demikian, dapat diartikan bahwa penambahan faktor produksi akan proporsional dengan penambahan produksi yang diperoleh.

c. Increasing return to scale, bila (b1 + b2 $+\ldots .+$ bn $)>1$. Dalam keadaan demikian, dapat diartikan bahwa proporsi penambahan faktor produksi akan menghasilkan tambahan produksi yang proporsinya lebih besar.

Tabel 3. Tingkat Skala Produksi Terhadap Hasil

\begin{tabular}{|c|c|c|c|}
\hline No. & Variabel & Koefisien & Return To Scale \\
\hline 1 & Lahan & $-0,690$ & Decreasing Return To Scale \\
\hline 2 & Tenaga Kerja & 0,222 & Decreasing Return To Scale \\
\hline 3 & Benih & 0,404 & Decreasing Return To Scale \\
\hline 4 & Urea & 0,613 & Decreasing Return To Scale \\
\hline 5 & SP-36 & $-0,181$ & Decreasing Return To Scale \\
\hline 6 & NPK & $-0,065$ & Decreasing Return To Scale \\
\hline 7 & Insektisida & $-0,069$ & Decreasing Return To Scale \\
\hline 8 & Herbisida & 0,060 & Decreasing Return To Scale \\
\hline & Jumlah & 0,294 & Decreasing Return To Scale \\
\hline
\end{tabular}


Nilai Return to scale pada usahatani padi sawah di Desa Tambakjati adalah 0,294. Hal ini menunjukkan bahwa usahatani padi sawah di Desa Tambakjati berada pada Decreasing return to scale (DRS). Dengan demikian, dapat diartikan bahwa proporsi penambahan faktor produksi akan menghasilkan tambahan produksi yang proporsinya lebih kecil. Apabila terjadi penambahan faktor produksi sebesar $1 \%$, maka akan menambahkan produktivitas sebesar $0,294 \%$.

\section{3) Efisiensi Teknis}

Menurut Budi Yoko et al. (2014), efisiensi teknis mencerminkan kemampuan petani untuk memperoleh output yang maksimal dari sejumlah input tertentu. Efisiensi teknis merupakan kombinasi dari perbandingan antara input dan output yang digunakan oleh petani untuk mendapat hasil yang maksimum.

Tabel 4. Elastisitas Produksi (Ep), Produksi Rata-rata (PR), dan Produksi Marginal (PM) Usahatani Padi Sawah $\alpha=5 \%$

\begin{tabular}{lcccc}
\hline \multicolumn{1}{c}{ Faktor Produksi } & Ep & PR & PM & Efisiensi Teknis \\
\hline Lahan (X1) & $-0,690$ & $3.790,23$ & $-2613,96$ & Tidak efisien \\
Tenaga Kerja (X2) & 0,222 & 201,26 & 44,75 & Belum efisien \\
Benih (X3) & 0,404 & 196,82 & 79,42 & Belum efisien \\
Urea (X4) & 0,613 & 26,99 & 16,55 & Belum efisien \\
SP-36 (X5) & $-0,181$ & 33,50 & $-6,06$ & Tidak efisien \\
\hline
\end{tabular}

Tabel 4 menunjukkan bahwa ada lima penggunaan faktor produksi yang berpengaruh secara nyata pada tingkat signifikansi 5\%, yaitu faktor produksi lahan, tenaga kerja, benih, urea, dan SP36 tetapi belum efisien secara teknis.

Penggunaan faktor produksi lahan memiliki nilai elastisitas produksi sebesar $-0,690$, artinya akan terjadi penurunan produktivitas padi sebesar $0,690 \%$ apabila penggunaan lahan ditambah sebanyak $1 \%$. Atau akan terjadi penurunan sebanyak $2.613,96 \mathrm{~kg}$ apabila lahan ditambah 1 hektar. Hal tersebut dapat dilihat pada Gambar 3. bahwa penggunaan lahan telah mencapai titik maksimum ketika penggunaan lahan seluas 2 hektar dengan rata-rata produktivitas sebanyak $3.790,23 \mathrm{~kg}$. Jika penggunaannya terus ditambah, maka akan menyebabkan inefisiensi. Salah satu penyebab lahan di Desa Tambakjati tidak efisien secara teknis, yaitu telah terjadinya penurunan produktivitas lahan yang diakibatkan oleh penggunaan pupuk anorganik yang tidak sesuai dengan dosis yang dianjurkan, sehingga kandungan organik lahan berkurang. Selain itu, ada 
Tingkat Efisiensi Teknis Usahatani Padi Sawah Di Desa Tambakjati, Kecamatan Patokbeusi, Kabupaten Subang, Provinsi Jawa Barat

Gina Rahnanita, Nur Syamsiyah

perbedaan produktivitas padi antara petani yang berlahan sempit, sedang dan luas. Petani yang berlahan sempit $(<0,5 \mathrm{Ha})$ memiliki produktivitas sebesar 4 ton/Ha, petani yang berlahan sedang (0,5-1 Ha) memiliki produktivitas sebesar 5,6 ton/Ha, sedangkan petani yang berlahan luas (>1Ha) memiliki produktivitas sebesar 5,19 ton/Ha. Sehingga petani yang berlahan sedang (0,5-1 Ha) lebih efisien daripada petani yang berlahan sempit maupun luas. Hal tersebut sejalan dengan pendapat Soekartawi (1999) makin luas lahan yang dipakai sebagai usaha pertanian, maka lahan tersebut semakin tidak efisien. Hal ini didasarkan pada pemikiran bahwa luasnya lahan mengakibatkan petani tidak mampu mengurus atau mengolah lahannya secara optimal. Selain itu, petani di Desa Tambakjati yang memiliki lahan pertanian yang luas umumnya mempunyai usaha di luar bidang pertanian. Sehingga waktu yang dicurahkan petani untuk mengelola usahatani sudah tidak menjadi prioritas lagi, karena penghasilan yang didapat dari luar usahatani lebih besar.

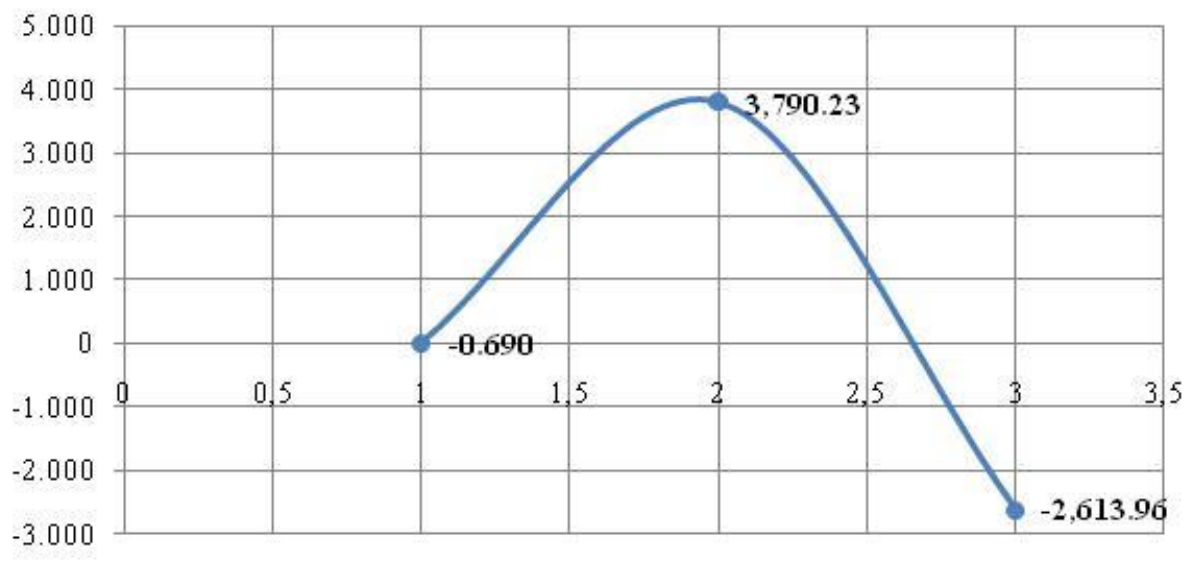

- Lahan (X1)

Gambar 3. Hukum The law diminishing return pada penggunaan lahan

Penggunaan faktor produksi tenaga kerja memiliki nilai elastisitas produksi sebesar 0,222, artinya akan terjadi kenaikan produktivitas padi sebesar $0,222 \%$ apabila penggunaan tenaga kerja ditambah sebanyak $1 \%$. Atau akan terjadi penambahan sebanyak 44,75 $\mathrm{kg}$ apabila lahan ditambah 1 HOK. Hal yang menyebabkan tenaga kerja belum efisien adalah kontribusi anggota rumah tangga tani kurang, sehingga curahan tenaga kerja dalam keluarga untuk lahan usahataninya belum maksimal.Untuk mencapai efisiensi teknis dalam penggunaan tenaga kerja, maka curahan 
tenaga kerja dalam keluarga harus ditambah.

Penggunaan faktor produksi benih memiliki nilai elastisitas produksi sebesar 0,404, artinya akan terjadi kenaikan produktivitas padi sebesar 0,404\% apabila penggunaan benih ditambah sebanyak 1\%. Atau akan terjadi penambahan sebanyak 79,42 $\mathrm{kg}$ apabila lahan ditambah $1 \mathrm{~kg}$. Menurut Balai Besar Penelitian Tanaman Padi (2015), penggunaan benih yang dianjurkan untuk 1 Ha lahan adalah sebanyak $20 \mathrm{~kg}$. Namun petani di Desa Tambakjati hanya menggunakan benih rata-rata sebanyak $18,67 \mathrm{~kg} / \mathrm{Ha}$, artinya untuk mencapai efisiensi teknis penggunaan benih harus ditambah sebanyak $1,33 \mathrm{~kg}$.

Penggunaan faktor produksi urea memiliki nilai elastisitas produksi sebesar 0,613, artinya akan terjadi kenaikan produktivitas padi sebesar $0,613 \%$ apabila penggunaan urea ditambah sebanyak 1\%. Atau akan terjadi penambahan sebanyak $16,55 \mathrm{~kg}$ apabila lahan ditambah $1 \mathrm{~kg}$. Menurut Balai Besar Penelitian Tanaman Padi (2015), penggunaan urea yang dianjurkan untuk 1 Ha lahan adalah sebanyak $300 \mathrm{~kg}$. Namun petani di Desa Tambakjati hanya menggunakan benih rata-rata sebanyak 139 kg/Ha, artinya untuk mencapai efisiensi teknis penggunaan benih harus ditambah sebanyak $161 \mathrm{~kg}$.

Penggunaan faktor produksi pupuk SP-36 memiliki nilai elastisitas produksi sebesar -0,181, artinya akan terjadi penurunan produktivitas padi sebesar 0,181\% apabila penggunaan pupuk SP-36 ditambah sebanyak $1 \%$. Atau akan terjadi pengurangan sebanyak $6,06 \mathrm{~kg}$ apabila lahan ditambah $1 \mathrm{~kg}$. Menurut Balai Besar Penelitian Tanaman Padi (2015), penggunaan pupuk SP-36 yang dianjurkan untuk 1 Ha lahan adalah sebanyak $100 \mathrm{~kg}$. Namun petani di Desa Tambakjati hanya menggunakan pupuk SP-36 rata-rata sebanyak $113 \mathrm{~kg} / \mathrm{Ha}$, artinya untuk mencapai efisiensi teknis penggunaan benih harus dikurangi sebanyak $13 \mathrm{~kg}$.

Hasil penelitian ini sesuai dengan penelitian yang dilakukan oleh Darwanto (2010), Kusnadi, Nunung., Netti, T., Sri H. S., \& Adreng P. (2016), dan Nizwar Syafa`at (2016), dimana benih, dan tenaga kerja memiliki hubungan yang positif dengan peningkatan efisiensi teknis usahatani padi sawah.

Penggunaan faktor produksi yang belum efisien menandakan bahwa apabila penggunaan faktor produksi ditambah, maka produktivitas masih akan bertambah (Tahap 1 hukum The law 
Tingkat Efisiensi Teknis Usahatani Padi Sawah Di Desa Tambakjati, Kecamatan Patokbeusi, Kabupaten Subang, Provinsi Jawa Barat

Gina Rahnanita, Nur Syamsiyah

diminishing return). Penggunaan faktor produksi yang tidak efisien menandakan bahwa apabila penggunaan faktor produksi ditambah, maka produktivitas akan turun (Tahap 3 hukum The law diminishing return).

\section{PENUTUP}

Berdasarkan hasil penelitian yang telah dilakukan, maka diperoleh kesimpulan yaitu:

1) Faktor produksi yang berpengaruh secara signifikan dan positif pada taraf nyata $5 \%$ terhadap produktivitas usahatani padi sawah di Desa Tambakjati adalah tenaga kerja, benih, dan urea. Hal tersebut memberikan makna bahwa setiap penambahan faktor produksi tersebut sebesar 1\%, maka akan menaikan produktvitas padi sebesar nilai koefisien regresi faktor produksi tersebut. Faktor produksi lahan dan SP-36 berpengaruh negatif terhadap produktivitas usahatani padi sawah.

2) Besarnya efisiensi teknis usahatani padi sawah di Desa Tambakjati, Kecamatan Patokbeusi pada signifikansi $5 \%$ adalah sebesar 0,037. Nilai tersebut menunjukkan bahwa usahatani padi sawah tidak efisien secara teknis apabila penggunaan lahan dan SP-36 terus ditambah. Dan akan akan mencapai efisiensi secara teknis apabila adanya penambahan penggunaan tenaga kerja, benih, dan urea.

Berdasaran hasil analisis di lapangan, terdapat beberapa rekomendasi yang dapat dilakukan oleh petani padi sawah agar dapat meningkatkan efisiensi dalam usahataninya, yaitu:

1) Efisiensi produksi usahatani padi sawah di Desa Tambakjati Kecamatan Patokbeusi masih memiliki peluang untuk ditingkatkan. Upaya peningkatan efisiensi produksi dapat ditempuh dengan cara mengoptimumkan penggunaan input usahatani seperti tenaga kerja, benih, dan urea.

2) Intensitas kegiatan penyuluhan pertanian harus ditingkatkan. Karena penyuluhan merupakan suatu kegiatan pendampingan para petani agar lebih terampil dalam mengkombinasikan input produksi. Jika terdapat permasalahan di lapangan petani dengan mudah meminta bantuan atau saran dari penyuluh sebagai pihak yang dianggap lebih memahami permasalahan budidaya padi.

3) Pemerintah melalui Dinas Pertanian Tanaman Pangan setempat perlu 
menerapkan kebijakan yang dapat merangsang aktivitas kelompok tani dan petugas penyuluh pertanian, sehingga dapat meningkatkan keterampilan manajemen usahataninya.

\section{DAFTAR PUSTAKA}

Badan Pusat Statistik. 2017. Hasil Survei Sosial Ekonomi Nasional 2017. Jakarta: BPS. . 2016. Jawa Barat Dalam Angka 2016. Bandung: BPS. 2016. Kabupaten Subang Dalam Angka 2016. Subang: BPS. 2016. Kecamatan Patokbeusi Dalam Angka 2016. Subang: BPS. . 2016. Hasil Sensus Pertanian Jawa Barat 2013. Bandung: BPS.

Balai Besar Penelitian Tanaman Padi. 2015. Pemupukan Pada Tanaman Padi.

http://bbpadi.litbang.pertanian.go.id /pemupukan_pada_tanaman_padi/ (Diakses tanggal 16 Februari 2018)

Balai Besar Penelitian Tanamn Padi. 2015. Budidaya Padi Sawah. http://bbpadi.litbang.pertanian.go.id /budidaya_tanaman_padi/http://bbp adi.litbang.pertanian.go.id/pemupu kan_pada_tanaman_padi/ (Diakses tanggal 16 Februari 2018).
Desa Tambakjati. 2017. Profil Desa Tambakjati. Tambakjati. Kantor Desa Tambakjati.

Mubyarto. 1989. Pengantar Ekonomi Pertanian. Edisi Ketiga. Jakarta: PT Pustaka LP3ES Indonesia.

Rodjak, A. 2006. Manajemen Usahatani. Bandung: Pustaka Giratuna.

Sarwono, J. 2006. Metode Penelitian Kuantitatif dan Kualitatif. Yogyakarta: Graha Ilmu.

Saptana, S. 2012. Konsep Efisiensi Usahatani Pangan dan Implikasinya bagi Peningkatan Produktivitas. Forum Penelitian Agro Ekonomi, 30(2): 109-128.

Soekartawi. 2003. Teori Ekonomi Produksi, dengan Pokok Bahasan Analisis Fungsi Produksi CobbDouglas. Cetakan Pertama. Jakarta: CV Rajawali

Sugiyono. 2012. Metode Penelitian Kuantitatif Kualitatif dan $R \& D$. Cetakan ke-17. Bandung: Alfabeta.

Sutanto, H. A., \& Imaningati, S. 2014. Tingkat Efisiensi Produksi Dan Pendapatan Pada Usaha Pengolahan Ikan Asin Skala Kecil. JEJAK: Jurnal Ekonomi dan Kebijakan, 7(1): 73-84.

Yoko, B., Yusman, S. dan Fariyanti, A. 2014. Analisis Efisiensi Usahatani Padi di Kabupaten Lampung Tengah. Jurnal Agribisnis Indonesia, 2(2): 127-140. 